section on filing and another on sales invoicing. A short bibliography and an index add to the value of the publication.

\section{Institution of Electrical Engineers : Annual Report}

AccordING to the report for the year 1943-44 of the Council of the Institution of Electrical Engineers, total membership on March 31, 1944, numbered 24,558 , and of those there were 11,924 corporate members ; 2,944 elections to all classes of membership were made during the previous twelve months. During the year 562 meetings were held in London and at the local centres. The Wireless Section held fifteen meetings, the Measurements Section eight, the Transmission Section eight, the Installations Section seven, and there were six informal meetings. There are nine students sections. Post-war planning has received close attention at the hands of the committee appointed for the purpose, and reports have been published on "Education and Training for Engineers", the "Organization of Post-War Electrical Research", and on "Electricity Supply, Distribution and Installation." A report on "Electricity in Post-War Building" has been completed by the Electrical Installations Committee and is being published by H.M. Stationery Office. The Council's report also deals with various phases of the Institution's war effort, with technical investigations, joint activities with other institutions, and with the subject of education. The revised eleventh edition of the Regulations for the Electrical Equipment of Buildings has been issued during the year.

\section{Monthly Astronomical Newsletter}

BART J. BoK, Harvard Observatory, prepares a Newsletter each month for the American Astronomical Society which is intended to keep scientific societies informed about progress in various branches of astronomy during the disruption of exchange of information. Some of the notes are duplicated in other publications, such as Sky and Telescope, and by Science Service. The present issue, No. 17, contains brief references to papers and notices in Harvard Announcement Cards, the Astrophysical Journal, Popular Astronomy, etc. A considerable portion is devoted to a review of contributions by Dr. N. T. Bobrovnikoff and others on the physical properties of comets.

\section{The Night Sky in July}

Full moon occurs on July 6d. 04h. 27m. U.T., and new moon on July 20d. $05 \mathrm{~h}$. $42 \mathrm{~m}$. The following conjunctions with the moon take place: July 18d. 08 h., Saturn $1^{\circ} \mathrm{N}$.; July 22d. 0lh., Mercury $0.7^{\circ} \mathrm{S}$.; July 22d. 20h., Jupiter $2^{\circ}$ S. ; July 23d. 11h., Mars $2^{\circ} \mathrm{S}$. The following conjunctions in addition to the above also take place: July 5d. 08h., Mars in conjunction with Jupiter, Mars $0 \cdot 2^{\circ}$ N. ; July 10d. 04h., Mars in conjunction with Regulus, Mars $0.7^{\circ} \mathrm{N}$.; July 20 d. $12 \mathrm{~h}$., Jupiter in conjunction with Regulus, Jupiter $0.5^{\circ}$ N.; July 28d. 08h., Mercury in conjunction with Regulus, Mercury $0 \cdot 01^{\circ} \mathrm{N}$.; July $29 \mathrm{~d}$. 17h., Mercury in conjunction with Jupiter, Mercury $0 \cdot 7^{\circ} \mathrm{S}$. Occultations of stars brighter than magnitude 6 are as follows: July 2d. 21h. $20 \cdot 9 \mathrm{~m} ., \theta$ Libr $(D)$; July 30d. 21h. $57 \cdot 7 \mathrm{~m}$., $\chi$ Ophi. $(D)$. The times refer to the latitude of Greenwich and $(D)$ means disappearance. Mercury is in inferior conjunction on July 1. At the middle of the month the planet sets $50 \mathrm{~m}$. after the sun and at almost the same interval at the end of July. Venus is too close to the sun to be conveniently observed until late in the month. On July 31 the planet sets less than half an hour after the sun. Mars, in the constellation of Leo, can still be observed as it sets $2 \mathrm{~h}$. after the sun at the beginning of July and $1 \mathrm{~h}$. $10 \mathrm{~m}$. after sunset on July 31. Jupiter, in the constellation of Leo, is drawing near the sun, setting only $50 \mathrm{~m}$. after sunset at the end of July. Saturn is no longer visible. The earth reaches aphelion on July 3 when its distance from the sun is 94,560,000 miles. An annular eclipse of the sun, invisible at Greenwich, takes place on July 20. At Bombay the magnitude of the eclipse is $0 \cdot 95$, at Hong Kong $0 \cdot 90$, and at Madras $0 \cdot 80$.

\section{Announcements}

THE following elections to the Royal Society have been made: fellow of the Royal Society under Statute 12 : the Right Hon. S. M. Bruce, High Commissioner for Australia in London. Foreign members: Dr. O. T. Avery, bacteriologist, member of the. Rockefeller Institute, New York; Prof. M. Lugeon, professor of general geology and stratigraphy in the University of Lausanne ; Prof. The Svedberg, professor of physical chemistry in the University of Uppsala; Prof. N. E. Svedelius, professor of botany in the University of Uppsala ; Prof. S. Timoshenko, professor of engineering mechanics in the University of Michigan.

THe director of the Chinese National Central Library has offered to provide British scholars with Chinese material for specialist researches, and to arrange for its translation into English if this is desired. The Library will also forward lists of books available to interested institutions in Great Britain. The British Council has undertaken to act as intermediary on the British side; all inquiries should be addressed to the Director, Books Department, British Council, 3 Hanover Street, London, W.1.

Two prizes of 200 dollars each, offered by Mr. A. Cressy Morrison, to be known as the A. Cressy Morrison Prizes in Natural Science, will be awarded in December 1944 by the New York Academy of Sciences. Papers, which must embody the results of original research not previously published, must be submitted on or before October 1, 1944, to the Executive Secretary of the New York Academy of Sciences, at the American Museum of Natural History, Central Park West at 79th Street, New York, N.Y.

THE University of Birmingham is to award AngloAmerican studentships to encourage research in some branch of petroleum technology. These studentships will normally be awarded for one year, but may be renewed for a second year, the value of the award being $£ 225$ for the first year and $£ 250$ for the second year, if renewed. They are open to graduates of the University of Birmingham and science graduates of other universities. Applications, which should include a statement of age, academic qualifications and career, should be submitted to the Registrar of the University of Birmingham by July 15. Applicants must also submit the names of two referees.

ErRatum. In the communication "Thermal Fatigue in Metals" by W. Boas and R. W. K. Honeycombe printed in Nature of April 22, p. 494, the illustration has been inverted: photomicrograph $d$ should be $a ; c$ should be $b ; b$ should be $c$; and $a$ should be $d$. 